\title{
Modeling of the financial market - the Kim-Markowitz type model for large and small investors
}

\author{
Marek Karaś (D), Anna Serwatka (iD
}

AGH University of Science and Technology, Faculty of Applied Mathematics, Krakow

\begin{abstract}
In the paper we consider a Kim-Markowitz type financial market model. We change the basic model (used in 1988 by Kim and Markowitz) and we add two groups of investors in relation to the size of the initial portfolio. The so-called small investors start with $100000 \$$ (as in the Kim-Markowitz model), and so-called large investors start with 4900000 \$. We want to check if the portfolio insurance strategy has a greater impact on small or large investors. First, we analyze simulations with rebalancers only, and we investigate whether a bigger difference of the initial percentage of shares in the portfolio among small and large investors will make one of these groups richer at the end of the simulation. Next, we add also Constant Proportion Portfolio Insurance investors. It is shown that in the normal/regular market (without very high intraday volatility of the stock price) the group of large investors obtain better result than the group of small investors. The existence of CPPI (constant proportion portfolio insurance) investors on the market makes the intraday volatility higher and so in there markets the large investors perform worse than small one.
\end{abstract}

Keywords: investment strategies, rebalansers, CPPI investors, small and large investors

\section{MODELOWANIE RYNKU FINANSOWEGO - MODEL TYPU KIMA-MARKOWITZA DLA DUŻYCH I MAŁYCH INWESTORÓW}

Streszczenie: W artykule rozważamy model rynku finansowego, w którym występują dwa typy inwestorów: ubezpieczyciele portfela oraz rebalanserzy. Podstawowy model został przedstawiony w 1988 roku przez Kima i Markowitza i posłużył do badania wpływu na rynek finansowy strategii ubezpieczycieli portfela. W podstawowym modelu wielkość początkowa portfela każdego inwestora wynosiła 100000 \$. Model przedstawiony w pracy skupia się na dwóch grupach inwestorów w zależności od wielkości portfela początkowego. Początkowa wartość portfela tak zwanych małych inwestorów wynosi 100000 \$ (jak w modelu Kima-Markowitza), natomiast tak zwani duzi inwestorzy w chwili początkowej mają portfele wartości 4900000 \$. W symulacjach sprawdzamy hipotezę, czy strategia ubezpieczenia portfelowego ma większy wpływ na małych czy dużych inwestorów. Najpierw analizujemy symulacje rynków, w których uczestniczą tylko rebalanserzy, i badamy, czy większa początkowa różnica procentowego udziałów akcji w portfelu pomiędzy małymi i dużymi inwestorami wpływa na większe bogacenie się jednej z grup. Następnie badamy rynki z udziałem ubezpieczycieli portfela. Wyniki symulacji, jakie otrzymujemy, pokazują, że na rynku normalnym/regularnym (bez bardzo dużej dziennej zmienności kursu akcji) grupa dużych inwestorów uzyskuje lepszy wynik niż grupa małych inwestorów. Dołączenie do symulacji ubezpieczycieli portfela (CPPI) powoduje, że zmienność w ciągu dnia jest wyższa oraz że na takich rynkach inwestorzy duzi radzą sobie gorzej niż mali.

Słowa kluczowe: strategie inwestycyjne, ubezpieczyciel portfela, rebalanser, mali i duzi inwestorzy https://doi.org/10.7494/978-83-66727-48-9_5 


\section{Introduction}

On October 19, 1987, the U.S. stock market fall more than $20 \%$ in a single day (called Black Monday). There were certainly many factors that contributed to this stock market crash. Scientists who studied the stock market crash in 1987 believe that the crash was caused by computer trading models, which used a portfolio insurance strategy (Carlson 2007). This situation showed the weaknesses of the trading systems in extreme conditions.

Portfolio insurance was one of program trading strategies used by investors in 1987. Under this strategy, computer trading models were used to compute predetermined ratios stock to cash. Kim and Markowitz analyzed this strategy in their paper (Kim and Markowitz 1989). We describe this case in the Section 2. In Kim-Markowitz model the value of starting portfolio of each investor was $100000 \$$. There are two groups of investors in relation to the size of the initial portfolio in our model in Section 2. The so-called small investors start with 100000 \$ (as in the Kim-Markowitz model), but so-called large investors start with 4900000 \$. We want to check if the portfolio insurance strategy has a greater impact on small or large investors. In the Section 3 we analyze only rebalancers strategy (Tokat 2007) and we investigate whether a bigger difference of the percentage of shares in the portfolio among small and large investors will make one of these groups richer at the end of the simulation. The simulation results and their interpretation are presented in the Section 4.

\section{Kim-Markowitz model description}

Consider a Kim-Markowitz financial market model (Kim and Markowitz 1989), where shares of one company and cash are available. They market model composed of two kinds of investors: rebalancers and portfolio insurers (the total number of investors is 150). There are no interest rates, stock pays no dividends and there are no transaction costs. In the model investors check their portfolios periodically and use their strategies. If the list of current sell and buy orders include orders that meets the price specification, the incoming order is executed immediately (sometimes in part). The unexecuted part is placed on the buy and sell list. In Kim-Markowitz model deposits and withdrawals are generated at random times in random amounts.

In all simulations there are three investor's prototypes: two rebalancers (prototype 1 start with $70 \%$ in stock and prototype 2 start with $30 \%$ in stock) and one CPPI (constant proportion portfolio insurance - see Section 2.2 below) investor prototype. The same specifications for all investors in each prototype, doesn't mean that they have the same simulated history, because the time and number of deposits and withdrawals is random and independent for each investor. Time for checking portfolio is also random. 
Let $w_{t}$ be the value of the portfolio at time $t, q_{t}$ the number of shares and $c_{t}$ be the cash that the investor has at the time $t$. Note that:

$$
w_{t}=q_{t} p_{t}+c_{t}
$$

is the value of the portfolio at time $t$, where $p_{t}$ is the share price at time $t$ in Kim and Markowitz (1989), and in our model $p_{0}=100 \$$ ). For CPPI agents we introduce the following: $f$ is the minimum level of affluence (so-called floor), $s_{t}$ - the value of the portfolio at time $t$ minus floor (so-called cushion).

The share price $p_{t}$ evolves depending on demand and supply. Trade does not take place continuously but at discrete points in time. Each investor reviews his portfolio at random intervals, estimates with individual predictions of prices as follows:

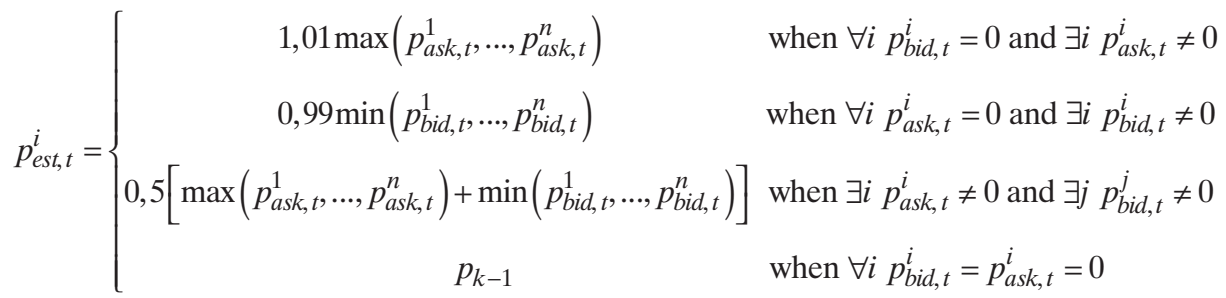

where $i$ is the agent number (agents are numbered from 1 to $n$ ), $p_{a s k, t}^{i}$ is the price, which is the maximum price that a $i$-th investor wants to pay for shares at time $t, p_{b i d, t}^{i}$ means the price represents the minimum price that a seller wants to receive. In both cases, for buyers and sellers, the offered price equal to zero ( $p_{a s k, t}^{i}$ or $\left.p_{b i d, t}^{i}\right)$ means the absence of the order. If there are only buy offers on the market (asks), the investor sets the estimated price at the level of $101 \%$ the highest ask price. If there are only offers for sale, the investor sets the price estimated at $99 \%$ the lowest bid price. If there are buy and sell offers, the investor assumes that the price will be between the bid and ask prices. The new price estimate is the average of the highest ask price and the smallest bid price from the previous period. If there are no offers, the investor takes the estimated price equal to the previous transaction price. When investor checks his portfolio, at a random moment, decides to buy, sell or do not give any offer. After determining the offer, the investor waits for offers from next agents. If there is a transaction, the share price changes into the transaction price. Each player can check his wallet once a day and set up a buy or sell offer. Prices and quantities are determined by supply and demand.

\subsection{Kim-Markowitz rebalancer's strategy}

Rebalancers are investors whose goal is to keep half of the portfolio's value in shares and half in cash: $q_{t} p_{t}=c_{t}=0.5 w_{t}$. In the Kim-Markowitz model, the assumption 
that the target ratio of shares to all assets for each rebalancer is 0.5 . Rebalancer offers a buy or sell offer if this ratio is less than 0.46 or greater than 0.55 . What is the impact of these investors on the market? The rebalancers strategy stabilizes the market. When the stock price goes up, rebalancers increase supply or reduce demand (the price increases - buy fewer shares). Declining stock price has the opposite effect and encourages rebalancers to reduce supply or increase demand (the price decreases buy more shares). If the ratio of the value of shares to the value of the entire portfolio is greater than $0.5\left(q_{t} p_{t} / w_{t}>0.5\right)$ the investor sets the bid $p_{b i d, t}^{i}=0.99 p_{e s t, t}^{i}$ and ask $p_{\text {ask }, t}^{i}=0$. On the other hand, if $\left(q_{t} p_{t} / w_{t}<0.5\right)$ he sets ask $p_{\text {ask }, t}^{i}=1.01 p_{\text {est }, t}^{i}$ and bid $p_{b i d, t}^{i}=0$. In addition, the investor determines how many shares he should sell or buy in the following way: let $x$ means the number of shares that the investor wants to buy or sell to make his portfolio meet the initial assumptions. Then:

1) if $q_{t} p_{t} / w_{t}>0.55$ then the rebalancer offer to sale $x_{b i d, t}^{i}$ shares at the price $p_{\text {bid, } t}^{i}=0.99 p_{\text {est }, t}^{i}$, where $x_{\text {bid,t }}^{i}$ satisfies the following equality:

$$
\left(q_{t}-x_{b i d, t}^{i}\right) p_{b i d, t}^{i}=0.5\left[\left(c_{t}+x_{b i d, t}^{i} p_{b i d, t}^{i}\right)+\left(q_{t}-x_{b i d, t}^{i}\right) p_{b i d, t}^{i}\right]
$$

or equivalently:

$$
\left(q_{t}-x_{b i d, t}^{i}\right) p_{b i d, t}^{i}=c_{t}+x_{b i d, t}^{i} p_{b i d, t}^{i}
$$

so:

$$
x_{b i d, t}^{i}=\frac{p_{b i d, t}^{i} q_{t}-c_{t}}{2 p_{b i d, t}^{i}}
$$

2) if $q_{t} p_{t} / w_{t}<0.46$ then the rebalancer offer to buy $x_{a s k, t}^{i}$ shares at the pric $p_{a s k, t}^{i}=1.01 p_{e s t, t}^{i}$, where $x_{a s k, t}^{i}$ satisfies the following equation:

$$
\left(q_{t}+x_{a s k, t}^{i}\right) p_{a s k, t}^{i}=0.5\left[\left(c_{t}-x_{a s k, t}^{i} p_{a s k, t}^{i}\right)+\left(q_{t}+x_{a s k, t}^{i}\right) p_{a s k, t}^{i}\right]
$$

or equivalently:

$\left(q_{t}+x_{a s k, t}^{i}\right) p_{a s k, t}^{i}=c_{t}-x_{a s k, t}^{i} p_{a s k, t}^{i}$

So:

$$
x_{a s k, t}^{i}=\frac{c_{t}-p_{a s k, t}^{i} q_{t}}{2 p_{a s k, t}^{i}}
$$




\subsection{Constant proportion portfolio insurance investors}

CPPI investors apply a strategy aimed at guaranteeing a minimum level of affluence (the so-called floor) within a specified period of expiration of insurance. They use constant proportion portfolio insurance proposed by Black and Jones (1987). The method can be described as maintaining the value of a risky asset, i.e. shares in a fixed proportion to the so-called 'cushion', which is the current value of the portfolio minus the floor. We can write their goal as:

$$
q_{t} p_{t}=k s_{t}=k\left(w_{t}-f\right)
$$

where $k>1$ in Kim and Markowitz (1989) and Samanidou (2006) is $k=2$.

Floor $f$ is defined as a fraction of the initial wealth and is constant throughout the entire insurance plan. What is the impact of these investors on the market? Constant proportion portfolio insurance strategy destabilizes the market: when prices fall, portfolio insurers will strive to protect their floors by reducing their storage position and if prices rise, they will try to raise their inventory position. The portfolio insurance plan has a start date and duration of the plan. The length of the insurance plan for portfolio insurers is 65 trading days, the target ratio of the stock to the cushion is 2 . When the simulation starts, the number of days remaining until the plan expires for each insurer is selected from the uniform distribution from 1 to 65. Expiration dates for different plans have been spread, so a simulation with a large number of CPPI investors will not be destabilized by plans starting on the same day. When one portfolio insurance plan ends, another plan begins for the next 65 days. The portfolio insurers buy shares, if the proportion of shares to the cushion is 1.7 and sell if the ratio is 2.3 . The value of the cushion is $25 \%$ of the initial value of the portfolio. The maximum ratio of shares to all assets for portfolio insurers is 1 . Kim-Markowitz simulated the market with the number of CPPI investors equal to $0,5,25,50,75$ and 100 out of 150 investors. There are some parameters for insurers. The first is floor, the minimum level of affluence at the expiration of insurance $f$. The floor is determined as a fraction of the initial wealth, and therefore is constant throughout the entire insurance plan. Next one is cushion the current value of the portfolio reduced by the floor $s_{t}=w_{t}-f$. The insurers strategy is to keep the value of the shares in proportion to the so-called cushion, so $k$ is a factor such that in Equation (9).

The initial value of the portfolio $w_{0}=q_{0} p_{0}+c_{0}$ in model is equal $100000 \$$ for all agents, and for CPPI investors there is an insurance level such that $f=g w_{0}$, in simulations $g=0.75$ (which means that on the expiry date losses should not exceed $25 \%$ of initial wealth). The investor checks his portfolio and sets the price $p_{\text {est }, t}^{i}$, if it is the day on which the new portfolio insurance plan starts, it sets the new floor, as $75 \%$ of the portfolio value, if it is a continuation of the plan, the floor is already set. Investor sets 
cushion $s_{t}=w_{t}-f$ and checks the ratio of the value of the shares to the value of the cushion, i.e. $q_{t} p_{t} / s_{t}$. If the ratio of the value of shares to the value of the cushion is greater than $k\left(q_{t} p_{t} / s_{t}>k\right)$ investor set bid $p_{b i d, t}^{i}=0.99 p_{\text {est }, t}^{i}$ and ask $p_{\text {ask,t }}^{i}=0$, otherwise, it sets the ask $p_{a s k, t}^{i}=1.01 p_{\text {est }, t}^{i}$ and bid $p_{b i d, t}^{i}=0$. In addition, the investor determines how many shares he should sell or buy in the following way: let $y$ means the number of shares that an investor wants to buy or sell to make his portfolio meet the initial assumptions. Then:

1) if $q_{t} p_{t} / s_{t}>k$ the insurer issues a sales offer $y_{b i d, t}^{i}$ shares at the price $p_{\text {bid,t }}^{i}=0.99 p_{\text {est }, t}^{i}$, where:

$$
\left(q_{t}-y_{b i d, t}^{i}\right) p_{b i d, t}^{i}=k\left(q_{t} p_{b i d, t}^{i}+c_{t}-f\right)
$$

so:

$$
y_{b i d, t}^{i}=q_{t}-\frac{k\left(p_{b i d, t}^{i} q_{t}+c_{t}-f\right)}{p_{b i d, t}^{i}}
$$

2) if $q_{t} p_{t} / s_{t}<k$ insurer issues a buy offer $y_{a s k, t}^{i}$ shares at the price $p_{a s k, t}^{i}=1.01 p_{e s t, t}^{i}$, where:

$$
\left(q_{t}+y_{a s k, t}^{i}\right) p_{a s k, t}^{i}=k\left(q_{t} p_{a s k, t}^{i}+c_{t}-f\right)
$$

SO:

$$
y_{a s k, t}^{i}=\frac{k\left(p_{a s k, t}^{i} q_{t}+c_{t}-f\right)}{p_{a s k, t}^{i}}-q_{t}
$$

3) otherwise, it does not issue a buy or sell offer.

The simulations of Kim-Markowitz model show how the volatility of the stock market depends on number of portfolio insurers versus number of rebalancers. Kim and Markowitz show that a market with 50\% CPPI investors and 50\% rebalancers is explosive.

\section{Kim-Markowitz type model for small and large investors}

In this section we want to investigate how groups of investors (large or small) are affected by the portfolio insurance strategy. We want to check what impact the strategy has on individual groups of investors when we change the percentage of insurers among all investors. The model is simplified, we assume two types of investors: 
rebalancers and portfolio insurers (as in the Kim-Markowitz model, see Tab. 1), no interest rate. Dividends are not paid and there are no transaction costs. For each simulation run, the number of investors of each type is determined, their initial portfolio value and what percentage of the portfolio they have in shares (see Tab. 2). The initial price of the shares on the first day is $p_{0}=100 \$$. Investors can sell or buy a maximum of $m=1000$ shares per day, if their strategy requires a larger number of shares bought or sold, the investor makes an order with volume $m=1000$ shares, and the rest of the required shares are purchased/sold in the next day/days. There is no limit in buying or selling shares in Kim-Markowitz model (Kim and Markowitz 1989).

Rebalancers are investors whose goal is to keep half of the portfolio's value in shares and half in cash. In the Kim-Markowitz model (Kim and Markowitz 1989), the assumption that the target ratio of shares to all assets for each rebalancer is 0.5 . Rebalancer offers a buy or sell offer if this ratio is less than 0.46 or greater than 0.55 . We enter the designation $B_{i}$ as the balance factor for the $i$-th rebalancer. In the present simulation, we now assume that for each rebalancer this coefficient is $B_{i}=0.5$, that is, each rebalancer strives to have half of the portfolio in shares and half in cash (in the future research we plan to make simulations with other than 0.5 values of $B_{i}$ and with different values of $B_{i}$ for different agents.

In Kim-Markowitz rebalancers check their portfolio in five days. We change it for everyday checking portfolio (Karaś and Serwatka 2021), but we add so-called chaotic strategy to their behavior. First rebalancer draws a number from the interval $(0,1)$ and takes the following actions: if it is a number from $(0,1 / 2)$, the investor does not take any action, if it is a number from the range $(1 / 2,98 / 100]$ it applies the rebalance strategy, if it is from therange $(98 / 100,1)$ then the rebalancer uses a chaotic strategy. The estimated price for chaotic strategy in our model is given by a formula $p_{\text {est }, t}^{i}=p_{t-1}+0.05 \varepsilon$, where $A \in(0,1)(A=0.05$ in present simulation $)$ and $\varepsilon \in[-1,1]$ is individually and randomly selected, when investor uses chaotic strategy. Next a number $\eta \in[-1 / 2,1 / 2]$ is selected. We assume that distribution is uniform, and we use it for the rest of the paper. When the investor has to use chaotic strategy, he checks portfolio and determines the value of the portfolio based on the estimated price $p_{\text {est }, t}^{i}$. Next, he draws a number $\eta \in[-1 / 2,1 / 2]$. If $\eta<0$ i.e. the investor wants to sell $|\eta|$ part of his shares. If $\eta>0$, i.e. the investor wants to buy shares at the price of $p_{\text {est }, t}^{i}$ allocating $\eta$ part of his cash. If $\eta=0$ the investor does not submit an offer. For CPPI investors we add that after reaching $133 \%$ the value of the initial portfolio the investor checks the parameters and change the floor, except as before when the 65-day insurance plan expires, too. We check two payout models.

First one (called model 1) is a model without deposits and withdraws. Model 2 is a model in which the investor draws a number from the range $(0,1]$. If the drawn number is in the range $(0 ; 0.1$ ], the investor has payout which for small investors means a payout drawn randomly from the range [0; 8000], and for large investors, the payout 
in the range $[0 ; 392000]$. If the drawn number is in the range $(0.1 ; 0.9]$, the investor has no payments and withdrawals. If the drawn number is in the range $(0.9 ; 1]$, the investor has the payment, which means a payment drawn randomly from the range [0;9000], for small investors and [0; 441000$]$ for large investors.

Table 1

Parameters for Kim-Markowitz and K-S simulations

\begin{tabular}{|l|c|c|}
\hline \multicolumn{1}{|c|}{ Parameter } & Kim-Markowitz & K-S \\
\hline Duration [days] & 400 & 400 \\
\hline Value of starting portfolio for small investors [\$] & 100000 & 100000 \\
\hline Value of starting portfolio for large investors [\$] & no large investors & 4900000 \\
\hline Number of small investors & 300 & 294 \\
\hline Number of large investors & 0 & 6 \\
\hline Maximum transaction volume & no limited & 1000 \\
\hline Initial price [\$] & 100 & 100 \\
\hline
\end{tabular}

Table 2

Parameters for groups of investors in simulations 1.1-2.12

\begin{tabular}{|l|c|c|c|c|c|c|}
\hline \multicolumn{1}{|c|}{ Parameter } & $\begin{array}{c}\text { Rebal1 } \\
\text { small }\end{array}$ & $\begin{array}{c}\text { Rebal2 } \\
\text { small }\end{array}$ & $\begin{array}{c}\text { Rebal3 } \\
\text { large }\end{array}$ & $\begin{array}{c}\text { Rebal4 } \\
\text { large }\end{array}$ & $\begin{array}{c}\text { CPPI1 } \\
\text { small }\end{array}$ & $\begin{array}{c}\text { CPPI2 } \\
\text { large }\end{array}$ \\
\hline Value of starting portfolio [\$] & 100000 & 100000 & 4900000 & 4900000 & 100000 & 4900000 \\
\hline Initial stock/(stock + cash) & 0.3 & 0.7 & 0.3 & 0.7 & 0.5 & 0.5 \\
\hline Target fraction of stock/total assets & 0.5 & 0.5 & 0.5 & 0.5 & - & - \\
\hline Rebalance if actual fraction is less than & 0.46 & 0.46 & 0.46 & 0.46 & - & - \\
\hline $\begin{array}{l}\text { Rebalance if actual fraction is greater } \\
\text { than }\end{array}$ & 0.55 & 0.55 & 0.55 & 0.55 & - & - \\
\hline Length of insurance plan [days] & - & - & - & - & 65 & 65 \\
\hline Target ratio of stock to cushion & - & - & - & - & 2.0 & 2.0 \\
\hline Actual ratio for buy stock & - & - & - & - & 1.7 & 1.7 \\
\hline Actual ratio for sell stock & - & - & - & - & 2.3 & 2.3 \\
\hline $\begin{array}{l}\text { Cushion as a fraction of portfolio } \\
\text { value: at start }\end{array}$ & - & - & - & - & 0.25 & 0.25 \\
\hline Cushion: start of new insurance plan & - & - & - & - & 0.25 & 0.25 \\
\hline Maximum ratio of stock to assets & - & - & - & - & 1.0 & 1.0 \\
\hline
\end{tabular}

In Table 3 we show that when the percentage of CPPI of agents in both groups increases, the tested value of the total portfolio of large to the value of the total portfolio of small investors decreases. It shows that the CPPI strategy has a big impact on the 
market, and when we look at the final profit or loss, a group of large investors gains less. In Table 4 we show the result of simulations 1.1-1.12 including $E(l / s)$ at time $t=T$, $\sigma\left(l_{T} / s_{T}\right), \min \left(l_{T} / s_{T}\right), \max \left(l_{T} / s_{T}\right)$. The result of simulations 2.1-2.12 are listed in Table 5.

Table 3

Number of investors in simulations 1.1-1.12. In simulations 2.1-2.12 the parameters and number of investors are the same - except deposit and withdrawal model, which is changed from model 1 to model 2

\begin{tabular}{|l|c|c|c|c|c|c|c|c|c|c|c|c|}
\hline \multirow{2}{*}{ Parameter } & \multicolumn{10}{|c|}{ Simulation number } \\
\cline { 2 - 16 } & 1.1 & 1.2 & 1.3 & 1.4 & 1.5 & 1.6 & 1.7 & 1.8 & 1.9 & 1.10 & 1.11 & 1.12 \\
\hline Rebal1 small & 147 & 123 & 98 & 74 & 49 & 245 & 98 & 196 & 49 & 196 & 98 & 147 \\
\hline Rebal2 small & 147 & 122 & 98 & 73 & 245 & 49 & 196 & 98 & 196 & 49 & 147 & 98 \\
\hline Rebal3 large & 3 & 2 & 2 & 1 & 5 & 1 & 4 & 2 & 4 & 1 & 3 & 2 \\
\hline Rebal4 large & 3 & 3 & 2 & 2 & 1 & 5 & 2 & 4 & 1 & 4 & 2 & 3 \\
\hline CPPI1 small & 0 & 49 & 98 & 147 & 0 & 0 & 0 & 0 & 49 & 49 & 49 & 49 \\
\hline CPPI2 large & 0 & 1 & 2 & 3 & 0 & 0 & 0 & 0 & 1 & 1 & 1 & 1 \\
\hline $\begin{array}{l}\text { Percentage of CPPI investors } \\
{[\%]}\end{array}$ & 0 & 17 & 33 & 50 & 0 & 0 & 0 & 0 & 17 & 17 & 17 & 17 \\
\hline $\begin{array}{l}\text { Percentage of shares in total } \\
\text { large investors portfolio at time } \\
t=0 \text { [\%] }\end{array}$ & 50 & 52 & 50 & 52 & 37 & 63 & 43 & 57 & 40 & 60 & 47 & 53 \\
\hline Deposit and withdrawal model & 1 & 1 & 1 & 1 & 1 & 1 & 1 & 1 & 1 & 1 & 1 & 1 \\
\hline
\end{tabular}

Table 4

The result of simulations 1.1-1.12

\begin{tabular}{|l|c|c|c|c|c|c|c|c|c|c|c|c|}
\cline { 2 - 12 } \multicolumn{1}{c|}{} & \multicolumn{10}{c|}{ Simulation number } \\
\cline { 2 - 12 } & 1.1 & 1.2 & 1.3 & 1.4 & 1.5 & 1.6 & 1.7 & 1.8 & 1.9 & 1.10 & 1.11 & 1.12 \\
\hline$E\left(\frac{l}{s}\right)$ at tim e $t=T$ & 0.999 & 0.882 & 0.771 & 0.701 & 1.038 & 1.037 & 1.007 & 1.009 & 0.834 & 0.918 & 0.857 & 0.890 \\
\hline$\sigma\left(\frac{l_{T}}{s_{T}}\right)$ & 0.004 & 0.021 & 0.040 & 0.056 & 0.016 & 0.019 & 0.005 & 0.005 & 0.019 & 0.026 & 0.022 & 0.019 \\
\hline $\min \left(\frac{l_{T}}{s_{T}}\right)$ & 0.983 & 0.827 & 0.696 & 0.597 & 0.992 & 0.994 & 0.988 & 0.990 & 0.792 & 0.863 & 0.805 & 0.832 \\
\hline $\max \left(\frac{l_{T}}{s_{T}}\right)$ & 1.004 & 0.938 & 0.876 & 0.836 & 1.054 & 1.059 & 1.014 & 1.016 & 0.888 & 0.990 & 0.922 & 0.939 \\
\hline
\end{tabular}


Table 5

The result of simulations $2.1-2.12$

\begin{tabular}{|l|c|c|c|c|c|c|c|c|c|c|c|c|}
\cline { 2 - 14 } \multicolumn{1}{c|}{} & \multicolumn{9}{c|}{ Simulation number } \\
\cline { 2 - 14 } & 2.1 & 2.2 & 2.3 & 2.4 & 2.5 & 2.6 & 2.7 & 2.8 & 2.9 & 2.10 & 2.11 & 2.12 \\
\hline$E\left(\frac{l}{s}\right)$ at time $t=0$ & 1 & 1 & 1 & 1 & 1 & 1 & 1 & 1 & 1 & 1 & 1 & 1 \\
\hline$\sigma\left(\frac{l}{s}\right)$ at time $t=T$ & 0.998 & 0.925 & 0.778 & 0.711 & 1.041 & 1.053 & 1.011 & 1.002 & 0.851 & 0.929 & 0.876 & 0.906 \\
\hline $\min \left(\frac{l_{T}}{s_{T}}\right)$ & 0.069 & 0.072 & 0.074 & 0.097 & 0.067 & 0.080 & 0.069 & 0.064 & 0.070 & 0.074 & 0.075 & 0.072 \\
\hline $\max \left(\frac{l_{T}}{s_{T}}\right)$ & 0.821 & 0.736 & 0.548 & 0.492 & 0.859 & 0.857 & 0.853 & 0.835 & 0.680 & 0.730 & 0.691 & 0.732 \\
\hline
\end{tabular}

In this section we want to investigate how groups of investors (large or small) are affected by the rebalancers strategy. We analyze only simulations with investors, who are rebalancers. We simulate markets with rebalancers strategy, but different value of Initial Stock/(Stock + Cash) (see Tab. 6). In Kim-Markowitz simulations there were two kinds of rebalancers: prototype 1 start with 70\% in stock and prototype 2 start with $30 \%$ in stock. We add simulations where in both groups large and small investors there are rebalancers, who start with $90 \%$ and $10 \%$ in stock. We do observations for 1040 or 400 days of simulations ( $T=1040$ or $T=400$ ). Table 7 shows portfolio structure in groups of rebalancers (small and large). In Table 7 we show how many investors are in each simulation from each prototype.

Table 6

Parameters for rebalancers in simulations $1.5-1.8$

\begin{tabular}{|l|c|c|c|c|c|c|c|c|}
\hline \multicolumn{1}{|c|}{ Parameter } & $\begin{array}{c}\text { Rebal1 } \\
\text { small }\end{array}$ & $\begin{array}{c}\text { Rebal2 } \\
\text { small }\end{array}$ & $\begin{array}{c}\text { Rebal3 } \\
\text { large }\end{array}$ & $\begin{array}{c}\text { Rebal4 } \\
\text { large }\end{array}$ & $\begin{array}{c}\text { Rebal5 } \\
\text { small }\end{array}$ & $\begin{array}{c}\text { Rebal6 } \\
\text { small }\end{array}$ & $\begin{array}{c}\text { Rebal7 } \\
\text { large }\end{array}$ & $\begin{array}{c}\text { Rebal8 } \\
\text { large }\end{array}$ \\
\hline $\begin{array}{l}\text { Value of starting } \\
\text { portfolio [\$] }\end{array}$ & 100000 & 100000 & 4900000 & 4900000 & 100000 & 100000 & 4900000 & 4900000 \\
\hline $\begin{array}{l}\text { Initial Stock/(Stock + } \\
\text { Cash) }\end{array}$ & 0.3 & 0.7 & 0.3 & 0.7 & 0.1 & 0.9 & 0.1 & 0.9 \\
\hline $\begin{array}{l}\text { Target fraction of } \\
\text { Stock/Total assets }\end{array}$ & 0.5 & 0.5 & 0.5 & 0.5 & 0.5 & 0.5 & 0.5 & 0.5 \\
\hline
\end{tabular}


Table 7

Number of investors in simulations 1.13-1.16 and results

\begin{tabular}{|l|c|c|c|c|}
\cline { 2 - 5 } \multicolumn{1}{c|}{} & \multicolumn{5}{c|}{ Simulation number } \\
\cline { 2 - 5 } \multicolumn{1}{c|}{} & 1.13 & 1.14 & 1.15 & 1.16 \\
\hline Rebal5 small & 0 & 200 & 0 & 800 \\
\hline Rebal1 small & 200 & 0 & 800 & 0 \\
\hline Rebal2 small & 800 & 0 & 200 & 0 \\
\hline Rebal7 large & 0 & 800 & 0 & 200 \\
\hline Rebal3 large & 0 & 16 & 0 & 4 \\
\hline Rebal4 large & 16 & 0 & 4 & 0 \\
\hline Rebal8 large & 4 & 0 & 16 & 0 \\
\hline$E\left(\frac{l}{s}\right)$ at time $t=0$ & 0 & 4 & 0 & 16 \\
\hline $\left.\begin{array}{l}\text { R } \\
(\end{array}\right)$ at time $t=T$ & 1 & 1 & 1 & 1 \\
\hline $\begin{array}{l}\text { Mean value of large market share at } \\
\text { time } t=0\end{array}$ & 0.51 & 0.53 & 0.51 & 0.54 \\
\hline
\end{tabular}

\section{Result of the simulations}

In the section we report obtained results and make its interpretation in the direction of the probable reason of the observed behavior. There are a few kinds of observation which can be done on the bases of the simulation made. The first observation is concerned with the markets without CPPI investors. In the simulation of such markets, it can be observed that the better results of the group of large investors versus the group of small investors (measured by $l_{T} / s_{T}$ or $E\left(l_{T} / s_{T}\right)$ ) is independent of whether at the time $t=0$ the large investors have more shares than small investors or the initial endowment in stock is such that the group of small investors have more shares than large investor. On the other hand, the same simulations show that if the initial endowment in stock is more far from the equilibrium (defined as the same number of shares in portfolios of the group of large investors as in the portfolios of small ones), then there is a bigger difference in obtained results of investment by the group of large investors versus results of investment obtained by the group of small ones 
(measured by $l_{T} / s_{T}$ or $E\left(l_{T} / s_{T}\right)$ ). To visualize the phenomenon, we define, for a given run of simulation the following quantity:

$$
X=\int_{0}^{T}\left|p_{L}-0.5\right| d t
$$

where $p_{L}$ denotes the fraction of all shares that are in portfolios of the large investors. It is rather natural to expect that the quantity $X$ is bigger when the initial endowment in stock is more far from the equilibrium. We do not investigate this relation and what is our concern is the relation between the quantity $X$ and $l_{T} / s_{T}$ or rather between $E(X)$ and $E\left(l_{T} / s_{T}\right)$, when of course, the expected value is taken over some large number $M$ (in our study $M=100$ ) of runs of the given simulation. In Figures 1-5 we observed the evolution in time of the following quantities: $E\left(l_{t} / s_{t}\right), E\left(l_{t} / s_{t}\right) \pm \sigma\left(l_{t} / s_{t}\right), \min \left(l_{t} / s_{t}\right)$, $\max \left(l_{t} / s_{t}\right)$, where expected value, standard deviation, minimum and maximum of $l_{t} / s_{t}$ (with $t=1, \ldots, T)$ is taken over some large number $(M=100)$ of runs of the given simulation. What can be observed is the fact that the starting at day number $t \in\{30, \ldots, 35\}$ there is a systematic growth of the observed quantities, of course with some local disturbance. It is rather expected behavior. On the other hand, it is observed, that in the range of time between the first day and a day of number $t \in\{30, \ldots, 35\}$ the observed quantities are decreasing. It is rather unexpected behavior and so one can be interested of the reason of such behavior. The explanation of such two different behaviors can be done if we consider the intraday volatility of the stock price. In Figure 6 it can be observed the evolution in time of the following simple measure of intraday volatility of the stock price:

$$
V_{t}=E\left(\max p_{t}-\min p_{t}\right)
$$

Where $\max p_{t}$ and $\min p_{t}$ denotes the maximal and minimal transaction price during the day number $t$ obtained in the given run of simulation and the expected value is taken over some large number $(M=100)$ of runs of the given simulations. It is visible that in the period of time between the first day and a day of number $t \in\{30, \ldots, 35\}$ the intraday volatility is rather high and then (after the day number $t \in\{30, \ldots, 35\}$ ) the intraday volatility is much smaller (this is not true in the cases of simulations with CPPI investors, see Figures $6 b-d)$.

Because the large investors are more exposed on an illiquidity problem it can be considered as an explanation of the decreasing of $E\left(l_{t} / s_{t}\right)$ in the range of days numbers $t \in\{1, \ldots, 35\}$. Since in the simulations $1.2-1.4$ in which the CPPI investors occur the 
intraday volatility is rather high in the whole range of time $t=1, \ldots, T$, it can be understandable why in markets in these simulations the large investors perform worse than small investors (see Figures 2-4).

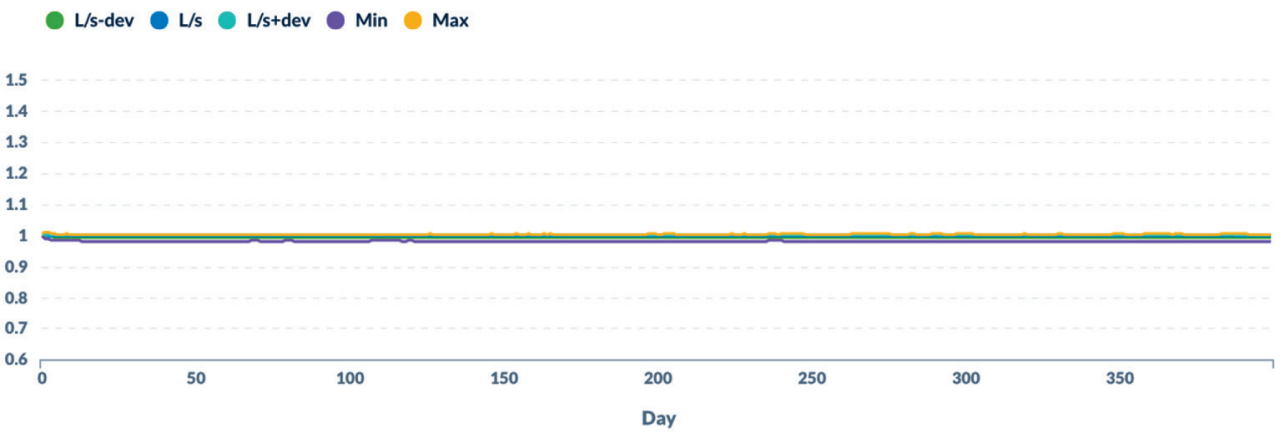

Fig. 1. $E\left(l_{t} / s_{t}\right), E\left(l_{t} / s_{t}\right) \pm \sigma\left(l_{t} / s_{t}\right), \min \left(l_{t} / s_{t}\right), \max \left(l_{t} / s_{t}\right)$ at time $t \in\{1, \ldots, 400\}$ for simulation 1.1

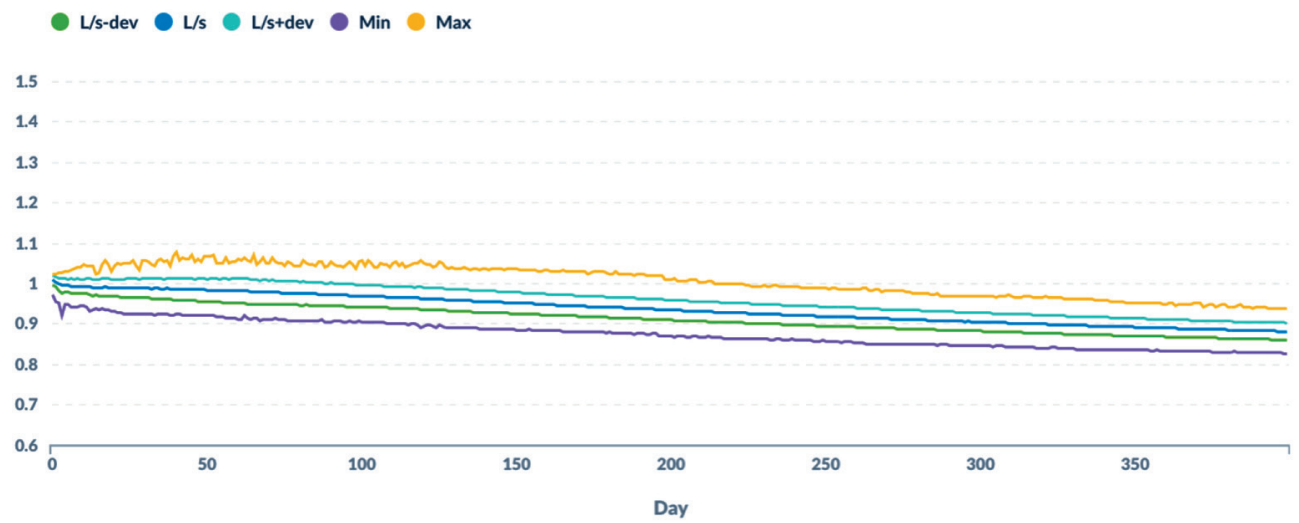

Fig. 2. $E\left(l_{t} / s_{t}\right), E\left(l_{t} / s_{t}\right) \pm \sigma\left(l_{t} / s_{t}\right), \min \left(l_{t} / s_{t}\right), \max \left(l_{t} / s_{t}\right)$ at time $t \in\{1, \ldots, 400\}$ for simulation 1.2

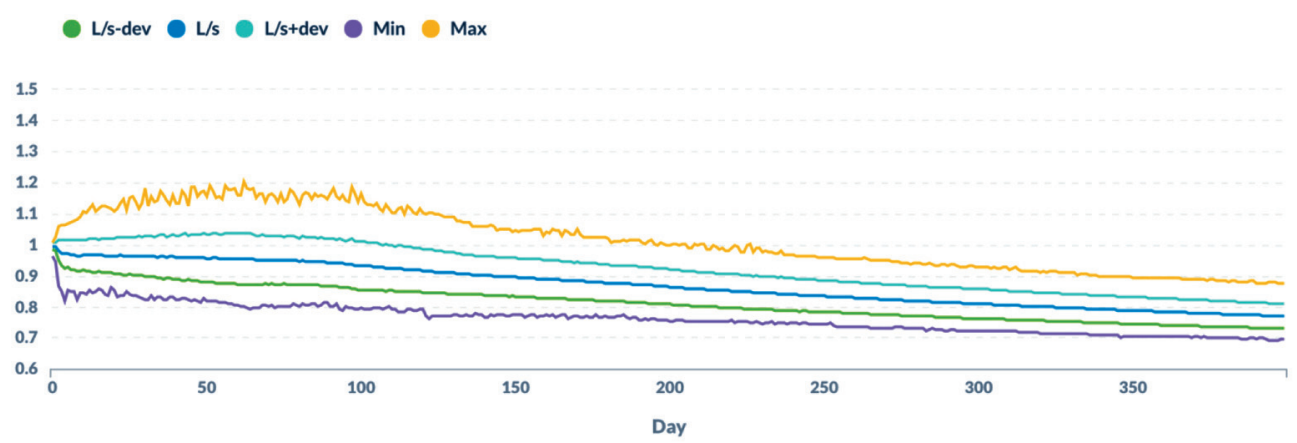

Fig. 3. $E\left(l_{t} / s_{t}\right), E\left(l_{t} / s_{t}\right) \pm \sigma\left(l_{t} / s_{t}\right), \min \left(l_{t} / s_{t}\right), \max \left(l_{t} / s_{t}\right)$ at time $t \in\{1, \ldots, 400\}$ for simulation 1.3 


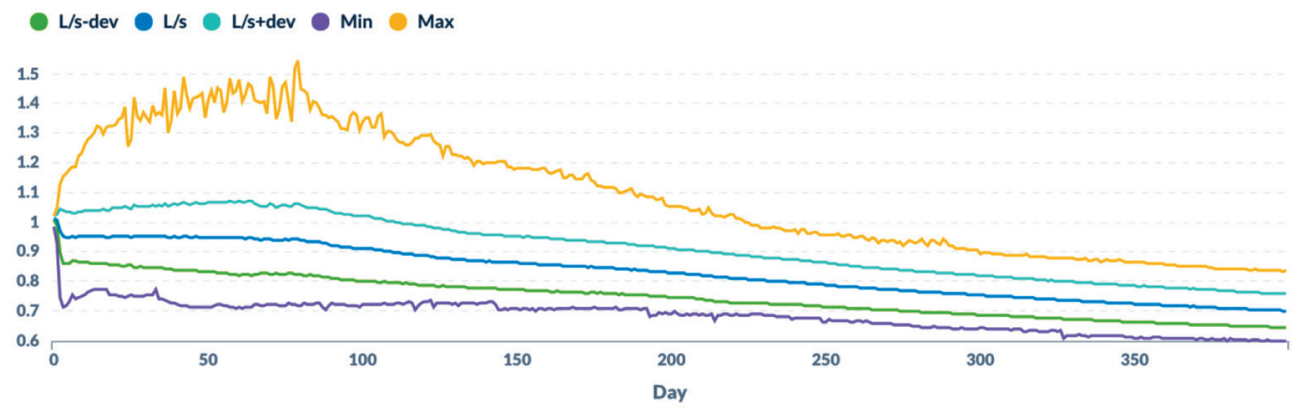

Fig. 4. $E\left(l_{t} / s_{t}\right), E\left(l_{t} / s_{t}\right) \pm \sigma\left(l_{t} / s_{t}\right), \min \left(l_{t} / s_{t}\right), \max \left(l_{t} / s_{t}\right)$ at time $t \in\{1, \ldots, 400\}$ for simulation 1.4

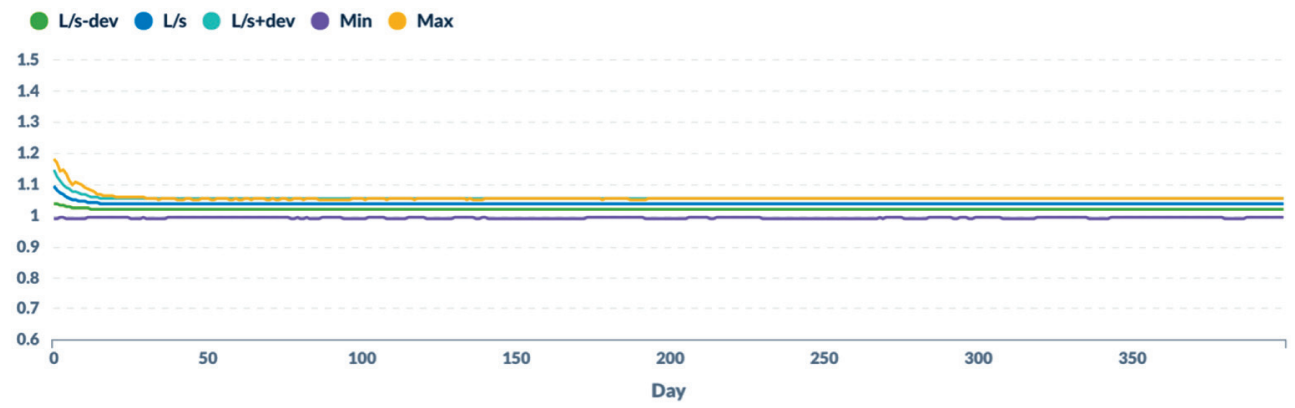

Fig. 5. $E\left(l_{t} / s_{t}\right), E\left(l_{t} / s_{t}\right) \pm \sigma\left(l_{t} / s_{t}\right), \min \left(l_{t} / s_{t}\right), \max \left(l_{t} / s_{t}\right)$ at time $t \in\{1, \ldots, 400\}$ for simulation 1.5

Simulation 1.1

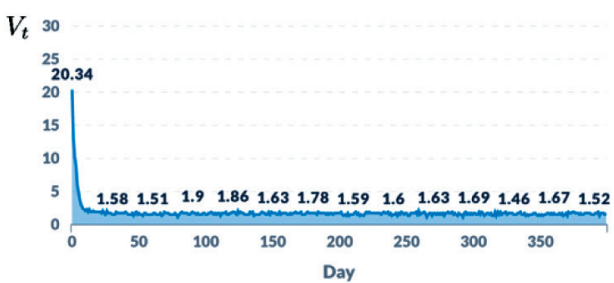

Simulation 1.3

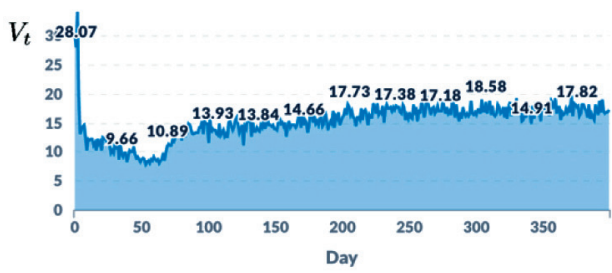

\section{Simulation 1.2}

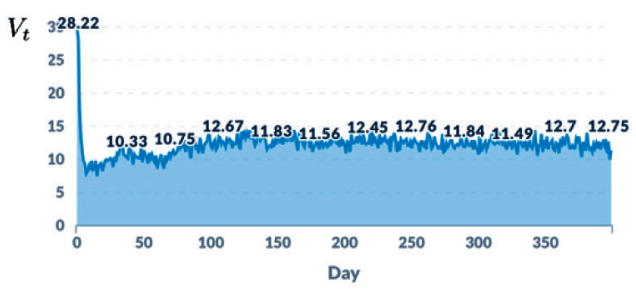

Simulation 1.4

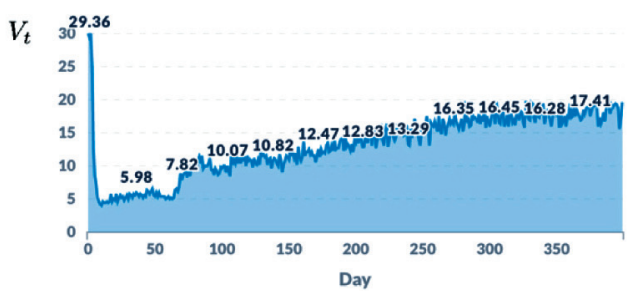

Fig. 6. The intraday volatility of the stock price (measured by the quantity $V_{t}$ defined by the Equation (15)) for simulations 1.1-1.4 
The relation between $E(X)$ and $E\left(l_{T} / s_{T}\right)$ is shown in Figures 7 and 8 .

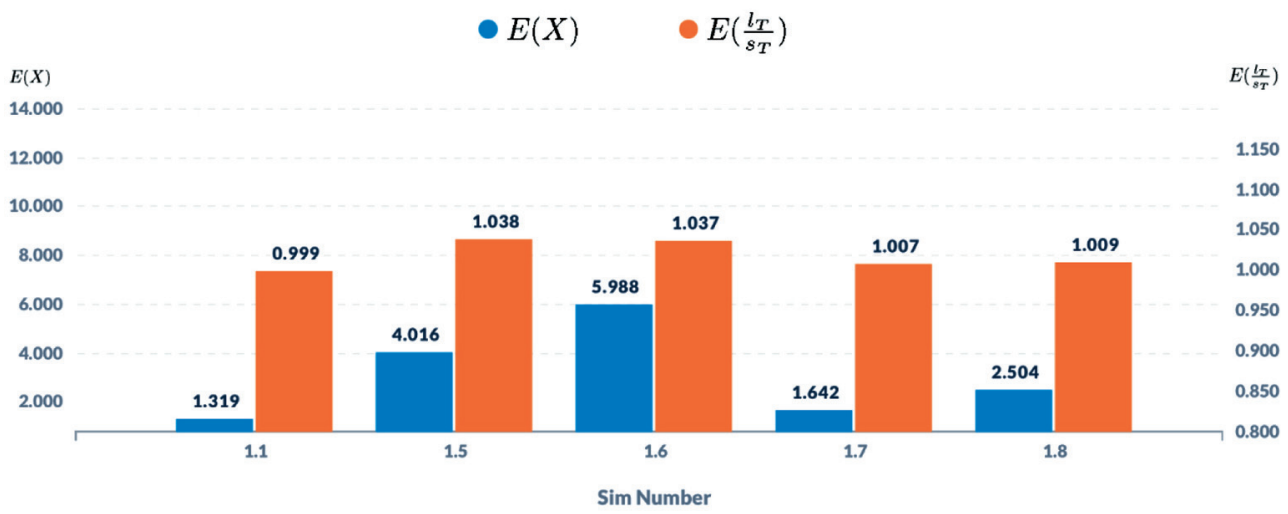

Fig. 7. The value of $E(X)$ and $E\left(l_{T} / s_{T}\right)$, i.e. at time $t=T$, for simulations 1.1, 1.5-1.8 - markets without CPPI investors

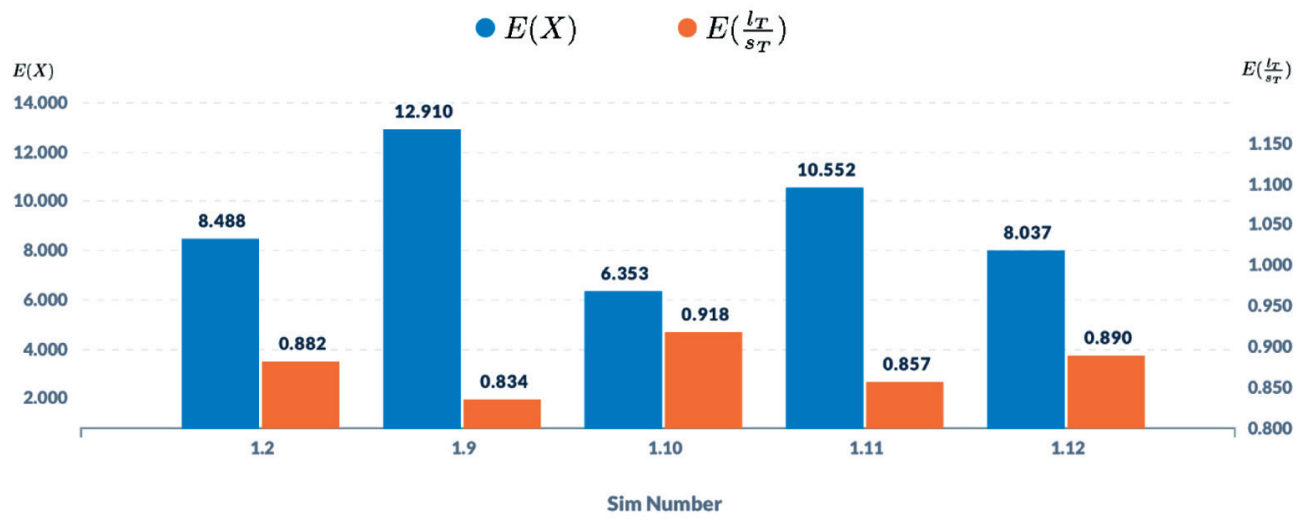

Fig. 8. The value of $E(X)$ and $E\left(l_{T} / s_{T}\right)$, i.e. at time $t=T$, for simulations 1.2, 1.9-1.12 - markets with CPPI investors

\section{Conclusions}

It is shown that in the normal/regular market (without very high intraday volatility of the stock price) the group of large investors obtain better result than the group of small investors. The advantage of large investors is positively correlated with the distance from the equilibrium (measured by the quantity $X$ defined by the Equation (14)). Moreover, the existence of CPPI investors on the market makes the intraday volatility higher and so in there markets the large investors perform worse than small one. Possible explanation of the last fact is the problem of lack of liquidity. 


\section{References}

Black F., Jones R.C., 1987, Simplifying portfolio insurance, The Journal of Portfolio Management, vol. 14, s. 48-51. https://doi.org/10.3905/jpm.1987.409131.

Carlson M.A., 2007, A Brief History of the 1987 Stock Market Crash with a Discussion of the Federal Reserve Response, FEDS Working Paper No. 2007-13. https://doi.org/ $10.2139 /$ ssrn. 982615 .

Karaś M., Serwatka A., 2021 [in press], Strong Hand Conjecture: Agent Based Numerical Simulation, Journal of Investment Strategies, vol. 10, no. 2.

Kim G., Markowitz H.M., 1989, Investment rules, margin and market volatility, Journal of Portfolio Management, vol. 16(1), s. 45-52. https://doi.org/10.3905/jpm.1989.409233.

Samanidou E., Zschischang E., Stauffer D., Lux T., 2006, Microscopic models of financial markets, Economics Working Papers, Department of Economics, Universitat Kiel 2006-15.

Tokat Y., Wicas N.W., 2007, Portfolio Rebalancing in Theory and Practice, The Journal of Investing, vol. 16(2), s. 52-59. https://doi.org/10.3905/joi.2007.686411. 